\title{
Pierwszy i jedyny preparat złożony beta-adrenolityku oraz inhibitora konwertazy angiotensyny w Polsce - po co? dla kogo? jakie ma główne zalety? jaką ma przyszłość?
}

\author{
Prof. dr hab. n. med. Krzysztof J. Filipiak \\ I Katedra i Klinika Kardiologii, Warszawski Uniwersytet Medyczny, Warszawa
}

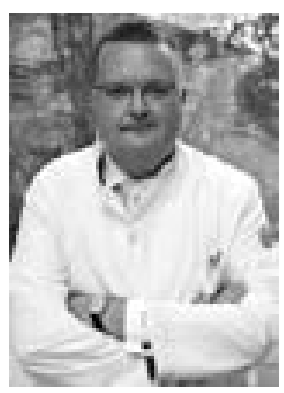

PO CO?

„Skojarzenie $\beta$-adrenolityku i inhibitora konwertazy angiotensyny (ACEI) jest prawdopodobnie jednym z najczęściej wykorzystywanych połączeń w kardiologii." — to zdanie pada na początku jednego z artykułów zaprezentowanych $w$ niniejszym suplemencie. Można zatem wyrazić zdziwienie, że dotychczasowy, szybko rozwijający się rynek preparatów hipotensyjnych nie znał dotychczas tego skojarzenia, chociaż zaznajomił już polskich pacjentów z połączeniami: ACEI z diuretykiem, ACEI z antagonistą wapnia, sartanów z diuretykiem, sartanów z antagonistą wapnia, $\beta$-adrenolityków z antagonistą wapnia, $\beta$-adrenolityków z diuretykiem, antagonistów wapnia z diuretykiem, a nawet pierwszych hipotensyjnych "trójek". Mieliśmy dotąd zatem siedem typów złożonych, dwuskładnikowych preparatów hipotensyjnych, a przybywa nam ósmy typ. Jako hipertensjolog pozwolę sobie zatem, idąc śladem rozważań zaprezentowanych przez Moich Kolegów — prof. Andrzeja Januszewicza i dra hab. Aleksandra Prejbisza, jeszcze raz zaznaczyć, że preparat Prestilol ${ }^{\circledR}$ uzupełnia bardzo ważną lukę na dotychczasowym rynku złożonych leków hipotensyjnych w Polsce, a jego znaczenie będzie rosło, m.in. ze względu na fakt, że takie połączenie, jako preferowane i zalecane, wprowadzono w wytycznych Polskiego Towarzystwa Nadciśnienia Tętniczego w 2015 roku.

\section{DLA KOGO?}

W odróżnieniu od innych siedmiu typów dwuskładnikowych połączeń hipotensyjnych, skojarzenie bisoprololu i perindoprilu ma jednak zdecydowanie szersze wskazania terapeutyczne. Każdy pacjent po zawale serca musi przyjmować ACEl i $\beta$-adrenolityk. W chorobie wieńcowej, bez przebytego zawału serca, ACEI przedłuża życie, a $\beta$-adrenolityk jest najważniejszym lekiem objawowym. To, łagodnie licząc, milionowa populacja pacjentów w Polsce, w której co prawda u 70-80\% chorych współistnieje nadciśnienie tętnicze, ale pozostali też wymagają stosowania obu substancji, chociaż ciśnienie tętnicze mają prawidłowe (idealne u tych ostatnich pacjentów byłoby podawanie najmniejszej zarejestrowanej dawki preparatu Prestilol ${ }^{\circledR}$ ). W przyszłości można sobie wyobrazić dalsze upraszczanie schematów terapeutycznych, dochodząc np. do dwutabletkowego modelu leczenia tych chorych (tabletka złożona $\beta$-adrenolityk/ACEl oraz tabletka złożona statyna/lek przeciwpłytkowy). Kolejna populacja pacjentów, często z prawidłowym ciśnieniem tętniczym, ale również wymagająca terapii ACEI i $\beta$-adrenolitykiem, to chorzy z niewydolnością serca. Również $w$ tej grupie mogę sobie w przyszłości wyobrazić dalsze upraszczanie schematów terapeutycznych, np. poprzez stosowanie dwóch tabletek (różne typy tabletek dwuskładnikowych zawierające odpowiednio połączenia: $\beta$-adrenolityku/ACEI/antagonisty receptorów mineralokrotykoidów/iwabradyny). Kolejne grupy chorych, u których zawsze stosuję ACEI, to pacjenci z cukrzycą, przewlekłą niewydolnością nerek lub innym ekwiwalentem wysokiego ryzyka sercowo-naczyniowego. Ponieważ u wielu z nich istnieją również wskazania do przyjmowania $\beta$-adrenolityku (współistniejąca choroba wieńcowa lub niewydolność serca lub nadciśnienie tętnicze lub migotanie przedsionków wymagające kontroli częstości rytmu komór lub inne formy arytmii), u części również zastosuję połączenie bisoprololu z perindoprilem. Zbiorcze oszacowanie liczby chorych, u których ewentualnie mógłbym rozważać wykorzystanie tego nowego preparatu, zostało przedstawione $\mathrm{w}$ tabeli 1.

Podsumowując, jako internista, widzę w preparacie Prestilol $^{\circledR}$ olbrzymi potencjał uproszczenia schematów terapeutycznych i redukcji liczby przyjmowanych tabletek u wielu moich pacjentów z grupy wysokiego ryzyka sercowo-naczyniowego, w tym osób z cukrzycą i/lub przewlekłą chorobą nerek, przyjmujących zarówno ACEI, jak i $\beta$-adrenolityki. 
Tabela 1. Autorska propozycja aktualnych wskazań terapeutycznych i możliwości rozważenia zastosowania preparatu złożonego bisoprolol/perindopril w praktyce klinicznej

\begin{tabular}{|c|c|}
\hline \multicolumn{2}{|c|}{$\begin{array}{c}\text { AKTUALNE WSKAZANIA TERAPEUTYCZNE } \\
\text { Preparat złożony: bisoprolol + perindopril } \text { (Prestilol }^{\circledR} \text { ) }\end{array}$} \\
\hline Wskazanie & Kiedy preparat złożony Prestilol ${ }^{\circledR}$ ? \\
\hline $\begin{array}{l}\text { CHOROBA NIEDOKRWIENNA SERCA/zawał serca/stan po zawale } \\
\mathbf{1} \text { mln osób }\end{array}$ & $\begin{array}{l}\text { Możliwość zastosowania u wszystkich chorych bez przeciwskazań } \\
\text { w celu uproszczenia schematów leczenia }\end{array}$ \\
\hline $\begin{array}{l}\text { NIEWYDOLNOŚC SERCA } \\
\mathbf{1} \text { mln osób }\end{array}$ & $\begin{array}{l}\text { Możliwość zastosowania u wszystkich chorych bez przeciwskazań } \\
\text { w celu uproszczenia schematów leczenia }\end{array}$ \\
\hline $\begin{array}{l}\text { Chory z grupy wysokiego ryzyka sercowo-naczyniowego } \\
\text { (ekwiwalent wieńcowy/cukrzyca/przewlekła choroba nerek) } \\
\text { 2-3 mln osób }\end{array}$ & $\begin{array}{l}\text { Możliwość rozważenia u większości chorych — częste nakładanie się } \\
\text { i wspótistnienie innych jednostek chorobowych }\end{array}$ \\
\hline $\begin{array}{l}\text { NADCIŚNIENIE TETNICZE } \\
9 \text { mln osób }\end{array}$ & Jedna z opcji leczenia hipotensyjnego \\
\hline
\end{tabular}

\section{JAKIE MA GŁÓWNE ZALETY?}

Dr hab. n. med. Filip M. Szymański spojrzał na preparat złożony z bisoprololu i perindoprilu z perspektywy kardiologicznej. Dodajmy, że poza przetoczonymi przez niego dowodami z kręgu medycyny opartej na faktach (EBM), ważna jest również codzienna praktyka polskich lekarzy. To oni właśnie wybierają najczęściej bisoprolol spośród wszystkich dostępnych $\beta$-adrenolityków, to oni też spośród ACEI najczęściej, obok ramiprilu, stosują perindopril. Dla kardiologa jest to zatem idealny lek do stosowania u osób z chorobą wieńcową i niewydolnością serca, a jego główne zalety to nie tylko dopasowanie do obowiązujących wytycznych leczenia obu jednostek chorobowych, ale również skład odpowiadający najczęściej przepisywanym lekom obu grup. Zwróciłbym jeszcze uwagę na zupełnie nowy obszar kardiologii, w którym zastosowanie połączenia $\beta$-adrenolityk/ACEI ma duże znaczenie. To prewencja niewydolności serca i swoista kardioprotekcja u wszystkich pacjentów leczonych chemio- i radioterapią uszkadzającą mięsień sercowy - a więc kardioonkologia. Tu też potencjał preparatu Prestilol ${ }^{\circledR}$ wydaje się interesujący.

Podsumowując, jako kardiolog, widzę w preparacie Prestilol ${ }^{\circledR}$ przede wszystkim lek upraszczający schematy leczenia choroby wieńcowej i niewydolności serca. Obecność dwóch najważniejszych leków kardiologicznych z punktu widzenia protekcji sercowo-naczyniowej ( $\beta$-adrenolityk oraz ACEI) w jednej tabletce pozwoli mi u wielu chorych bez nadciśnienia tętniczego, a nawet z niskim ciśnieniem tętniczym, wdrożyć tę terapię, zaczynając od najmniejszej potencji preparatu, dochodząc do dawek optymalnych.

\section{JAKĄ MA PRZYSZŁOŚĆ?}

Próbując odpowiedzieć na pytanie, jaką przyszłość można wywróżyć Prestilolowi ${ }^{\circledR}$ na polskim rynku farmaceutycznym, warto odwołać się do sprzedaży (a więc "przepisywalności” recept) liczby opakowań podstawowych leków hipotensyj-

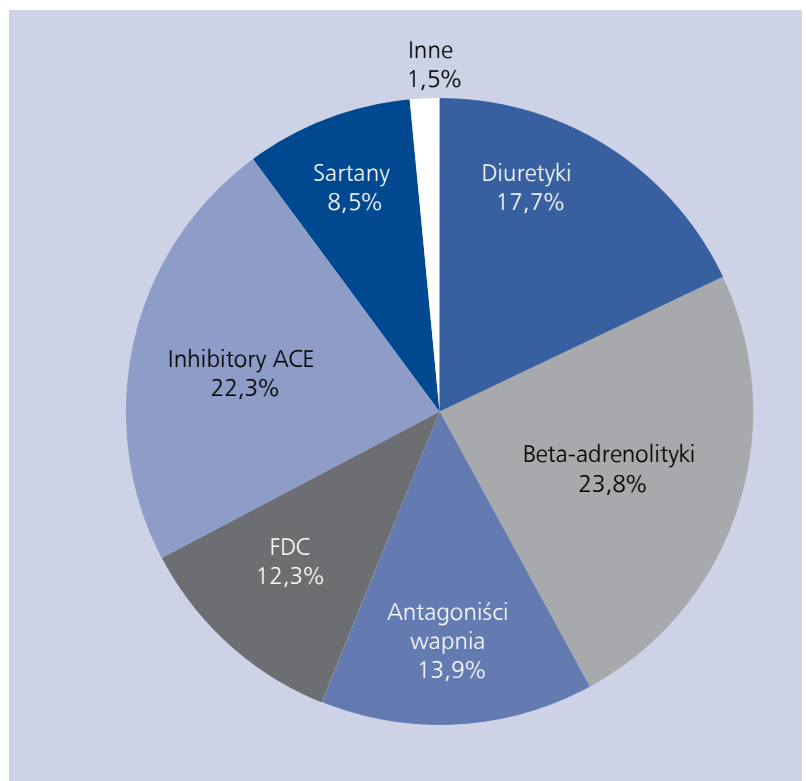

Rycina 1. Sprzedaż różnych kategorii preparatów hipotensyjnych w Polsce pod koniec 2016 roku. Dane, za zgodą, wg IMS, Polska; ACE — konwertaza angiotensyny; FDC preparaty złożone z co najmniej dwóch leków

nych w Polsce. Według danych IMS, na blisko 130 milionów opakowań tych leków sprzedawanych rocznie w Polsce złożone leki hipotensyjne (FDC, fixed dose combination) stanowiły na koniec roku ponad $12 \%$ sprzedawanych preparatów. Ale to, co może w przyszłości decydować o pozycji takich preparatów, jak Prestilol ${ }^{\circledR}$, to fakt, że najczęściej sprzedawane w Polsce leki hipotensyjne to właśnie $\beta$-adrenolityki oraz ACEI — razem grupy te stanowią blisko połowę rynku preparatów hipotensyjnych. Polska jest pod tym względem krajem, w którym popularność tych dwóch grup leków jest wyjątkowo duża. Wyobraźmy sobie, że osoby dotychczas przyjmujące $\beta$-adrenolityki i ACEI równocześnie wybierają prostszą formę 
terapii - preparat Prestilol $^{\circledR}$. Analizując rycinę 1, widzimy, jaki potencjał reprezentuje sobą ten właśnie preparat.

A przecież będziemy go stosować nie tylko w nadciśnieniu tętniczym, ale również u osób bez nadciśnienia tętniczego, leczonych wg zaleceń dotyczących niewydolności serca i stabilnej choroby wieńcowej, o czym wspominałem w moim komentarzu. Jako farmakolog kliniczny sądzę zatem, że ten właśnie preparat złożony może wejść do armamentarium podstawowych leków stosowanych w Polsce w ciągu kilku zaledwie lat. Jest złożeniem dwóch leków najpopularniejszych klas substancji hipotensyjnych, może być stosowany we wszystkich trzech podstawowych chorobach kardiologicznych (nadciśnienie tętnicze, choroba wieńcowa, niewydolność serca), pozwala uprościć schematy terapeutyczne, stanowi istotną nowość na polskim rynku preparatów złożonych. Jest pierwszy!

Konflikt interesów: dotyczący udziału w konferencjach $i$ wykładach organizowanych przez: Adamed, AstraZeneca, Bayer, Berlin Chemie, Boehringer Ingelheim, Krka, Merck, MSD, Mylan, Pfizer, Polpharma, Recordati, Sandoz, Sanofi, Servier, Valeant. 